\title{
KEANEKARAGAMAN JENIS IKAN DARI EKOSISTE MANGROVE DI DESA PAGATAN BESAR, KABUPATEN TANAH LAUT, PROVINSI KALIMANTAN SELATAN
}

\author{
Anang Kadarsah ${ }^{1}$, Maulida Turrahmah ${ }^{1}$, Abdul Gafur ${ }^{1}$ \\ ${ }^{1}$ Jurusan Biologi Universitas Lambung Mangkurat \\ E-mail: anangkadarsah@ulm.ac.id
}

\begin{abstract}
The existence of mangrove ecosystems in Pagatan Besar Village of Tanah Laut Regency provides benefits for a variety of fish and the surrounding waters. This study aims to identify the diversity of fish species from mangrove and coastal ecosystems in Pagatan Besar Village, Tanah Laut Regency. The research method use a survey methods and fishing use a purposive sampling based on the differences of habitat conditions. The parameters was measured including fish species, density, diversity index, evenness index, and similarity index. The results showed that found as many as 18 species of fish from the mangrove forest and even more from the coast (20 types). Belama fish (Argyrosomus sp.; Scienidae) is the type of fish most commonly found in the mangrove forests $(31.31 \%)$ while on the coast are Klepes fish (Amblygaster leiogaster: Clupidae) with the value is $44.96 \%$. The average abundance of fish from the mangrove forest is 66 individuals $/ m 2$ of fish nets) smaller than coastal fishing (94.17 individuals/m2 of fish nets). Diversity index of fish from the mangrove forest was 2.12 and from the coast is smaller (1.68). Evenness Index from mangrove forests is higher (1.68) compared to the coast (1.29). And the similarity index number of fish species in mangrove forests and coastal areas was $58.3 \%$.
\end{abstract}

Keywords: Fish, Mangrove forest, Coastal, Diversity

\section{PENDAHULUAN}

$\mathrm{K}$ eanekaragaman ikan yang terdapat ekosistem mangrove, baik yang menetap atau hanya transit untuk melakukan pemijahan serta untuk memelihara anakannya akan menambah keanekaragaman hayati pada ekosistem tersebut (Puteri, Sitorus, \& Muhtadi, 2017). Menurut (Kottelat, Whitten, Kartikasari, \& Wirjoatmodjo, 1993) ikan berperan dalam menjaga keseimbangan siklus rantai makanan di dalam ekosistem perairan. Sedangkan pendapat (Hendrata, 2004) mengatakan ikan juga dapat dijadikan sebagai bioindikator terhadap kualitas perairan khususnya pada sistem pengolahan air limbah rumah sakit.

Salah satu indikator dari optimal dan lestarinya kondisi hutan mangrove adalah stabilnya struktur dan komposisi serta tingkat keanekaragaman flora dan fauna yang dimiliki oleh hutan mangrove tersebut . Keanekaragaman jenis merupakan parameter yang digunakan dalam mengetahui suatu komunitas, parameter ini mencirikan kekayaan jenis dan keseimbangan dalam suatu komunitas (Krebs, 1972). Ekosistem dengan 
keanekaragaman rendah tidak stabil dan rentan terhadap pengaruh dari luar dibandingkan dengan ekosistem yang memiliki keanekaragaman yang tinggi (Boyd, 2003).

Kawasan pesisir pantai di Desa Pagatan Besar merupakan salah satu dari sekian banyak pantai di Kalimantan Selatan dengan karakteristik pantai bertipe landai dan datar. Hasil pengamatan menunjukkan ada tiga jenis ekosistem ditemukan di Desa Pagatan Besar yaitu; estuaria, hutan mangrove dan pantai lurus. Estuaria yang berada di sana merupakan muara dari Sungai Pagatan yang bersambung dengan ekosistem mangrove sebagai kawasan ekowisata yang dibina oleh Dinas Perikanan dan Kelautan Kabupaten Tanah Laut.

Hingga saat ini belum ada laporan mengenai keanekaragaman jenis ikan yang terdapat di kawasan perairan mangrove dan pesisir pantai Desa Pagatan Besar, padahal informasi tersebut sangat diperlukan untuk pengelolaan sumber daya ikan yang berkelanjutan di Desa Pagatan Besar yang berbasis ekonomi, pendidikan, dan ekologi oleh karena itu diperlukan adanya informasi mengenai keanekaragaman jenis ikan melalui penelitian ini dapat dijadikan landasan studi lebih lanjut terutama untuk pengelolaan sumber daya ikan di Desa Pagatan Besar.

\section{METODE PENELITIAN}

Metode yang digunakan pada pengamatan biodiversitas ikan ini antara lain (1) kajian pustaka yakni menelaah beberapa pustaka dari buku, internet, jurnal dan penelitian sebelumnya untuk mendapatkan teori dan data dalam memperkuat pembahasan. (2) Pengambilan sampel ikan secara langsung menggunakan jala berukuran $60 \times 1,5$ meter, sedangkan penentuan lokasi menggunakan metode simple random sampling. (3) Analisis data meliputi : identifikasi jenis ikan menggunakan petunjuk (Allen, 2000), (Nasution, Sulistiono, \& Haryani, 2004), (Kottelat et al., 1993), dan (Saanin, 1984); penghitungan nilai kelimpahan ikan (individu/hektar); penghitungan indeks keanekaragaman ikan menggunakan Shannon-Wiener; penghitungan indeks kemerataan jenis (Evenness), dan penghitungan indeks kesamaan menggunkan rumus Jaccard (Krebs, 1972).

\section{HASIL DAN PEMBAHASAN}

\section{A. Lokasi Penelitian}

Kawasan ekosistem mangrove Desa Pagatan Besar, Kabupaten Tanah Laut, Provinsi Kalimantan Selatan. Lokasi penelitian berada di sebelah selatan Kota Banjarmasin dengan jarak perjalanan sejauh $70 \mathrm{~km}$ dan waktu tempuh menggunakan kendaraan kurang lebih selama 1 jam 48 menit (http://shorturl.at/twGOT) .Ekosistem mangrove di desa ini memiliki dua jenis karakteristik pantai yang berbeda. Pertama, hutan mangrove di kawasan estuaria dengan kondisi substrat berlumpur sebagai bagian wilayah muara Sungai Pagatan. Kedua adalah pantai lurus atau sering disebut sebagai pesisir karang gosong yang jarang memiliki vegetasi dan cenderung terbuka sehingga banyak dimanfaatkan penduduk untuk menangkap ikan menggunakan jala lempar ataupun jaring bentang. Menurut (Nybakken, 1992) pantai lurus sering ditemukan pada dataran pantai landai serta mempunyai sedimen berupa lumpur hingga pasir kasar. 


\section{B. Perbandingan Jenis Ikan dari Hutan Mangrove dan Pesisir}

Hasil pengamatan dan perhitungan tercatat ada sebanyak 18 jenis ikan dan 12 famili yang ditemukan dari hutan mangrove Desa Pagatan Besar, sedangkan dari pesisir pantai ditemukan lebih banyak lagi yakni 20 jenis dan 15 famili. Jenis ikan yang hanya ditemukan pada hutan mangrove antara lain : Clupeonella cultriventris, Anchoviella juruasanga, Drepane punctata, dan Pseudapocryptes elongates. Sedangkan ikan yang hanya ditemukan pada pesisir pantai adalah Amblygaster leiogaster, Tetraodin retricunaris, Chanos chanos, Eleutheronema tetradactylum, Later calarifer, dan Dasyatis Americana. Data keanekaragaman jenis-jenis ikan yang ditemukan pada ekosistem mangrove di Desa Pagatan Besar dapat dilihat pada Tabel 1 di bawah ini.

Tabel 1. Keanekaragaman jenis-jenis ikan yang ditemukan pada ekosistem mangrove di Desa Pagatan Besar Kabupaten Tanah Laut.

\begin{tabular}{|c|c|c|c|c|c|c|}
\hline \multirow[b]{2}{*}{ No. } & \multirow[b]{2}{*}{ Famili / Spesies } & \multicolumn{4}{|c|}{ Jumlah } & \multirow[b]{2}{*}{ Sig. } \\
\hline & & $\begin{array}{l}\text { Stasiun I } \\
\text { Hutan } \\
\text { Mangrove }\end{array}$ & $\%$ & $\begin{array}{c}\text { Stasiun II } \\
\text { Pesisir Pantai }\end{array}$ & $\%$ & \\
\hline \multirow[t]{8}{*}{1.} & Clupeidae & & & & & \\
\hline & Amblygaster leiogaster & - & - & $254 *$ & 44,9 & 0,024 \\
\hline & Sardinella brachysoma & 20 & 5,05 & 23 & 4,07 & 1,000 \\
\hline & 3. $\quad$ Sardinella albella & 3 & 0,75 & 3 & 0,53 & 0,012 \\
\hline & 4. Dorosoma petenense & 4 & 1,01 & 20 & 3,53 & 0,256 \\
\hline & 5. Anodontostoma chacunda & $34^{\mathrm{a}}$ & $\mathbf{8 , 5 8 ^ { b }}$ & $26^{b}$ & $4,6^{a}$ & $\mathbf{0 , 0 0 2}$ \\
\hline & 6. Dussumieria acuta & 7 & 1,76 & 9 & 1,59 & 0,515 \\
\hline & 7. $\quad$ Clupeonella cultriventris & 38 & 9,56 & - & - & 0,145 \\
\hline \multirow[t]{3}{*}{2.} & Engraulidae & & & & & \\
\hline & 8. Anchoa lyolepis & 97 & 24,49 & 19 & 3,36 & 0,049 \\
\hline & 9. Anchoviella juruasanga) & 1 & 0,25 & - & - & 0,341 \\
\hline \multirow[t]{2}{*}{3.} & Drepaneidae & & & & & \\
\hline & 10. Drepane punctate & 4 & 1,01 & - & - & 0,260 \\
\hline \multirow[t]{2}{*}{4.} & Carangidae & & & & & \\
\hline & 11. Selaroides leptolepis & 4 & 1,01 & 4 & 0,7 & 0,673 \\
\hline \multirow[t]{2}{*}{5.} & Mugilidae & & & & & \\
\hline & 12. Moolgarda seheli & 20 & 5,05 & 4 & 0,7 & 0,073 \\
\hline \multirow[t]{2}{*}{6.} & Oxudericidae & & & & & \\
\hline & 13. Pseudapocryptes elongates & 6 & 1,51 & - & - & 0,016 \\
\hline \multirow[t]{2}{*}{7.} & Scombridae & & & & & \\
\hline & 14. Thunnus tonngol & 4 & 1,01 & 6 & 1,06 & 0,727 \\
\hline \multirow[t]{2}{*}{8.} & Scienidae & & & & & \\
\hline & 15. Argyrosomus sp. & $124 *$ & 31,31 & 168 & 29,7 & 0,541 \\
\hline \multirow[t]{2}{*}{9.} & Soloidae & & & & & \\
\hline & 16. Brachirus oriental & 6 & 1,51 & 2 & 0,35 & 0,341 \\
\hline \multirow[t]{2}{*}{10.} & Sillaginidae & & & & & \\
\hline & 17. Sillago acuta & 6 & 1,51 & 10 & 1,76 & 1,000 \\
\hline \multirow[t]{2}{*}{11.} & Trichiuridae & & & & & \\
\hline & 18. Trichiurus lepturus & 9 & 2,27 & 1 & 0,17 & 0,614 \\
\hline \multirow[t]{2}{*}{12.} & Plotosidae & & & & & \\
\hline & 19. Plotosidae) & $9^{b}$ & $2,27^{b}$ & $7^{a}$ & $1,23^{a}$ & $\mathbf{0 , 0 0 0}$ \\
\hline \multirow[t]{2}{*}{13.} & Tetradontidae & & & & & \\
\hline & 20. Tetraodin retricunaris & - & - & 3 & 0,53 & 0,049 \\
\hline \multirow[t]{2}{*}{14.} & Chanidae & & & & & \\
\hline & 21. Chanos chanos & - & - & 3 & 0,53 & 0,021 \\
\hline
\end{tabular}




\begin{tabular}{|c|c|c|c|c|c|c|}
\hline 15. & Polynemidae & & & & & \\
\hline & Eleutheronema tetradactylum & - & - & 1 & 0,17 & 0,341 \\
\hline \multirow[t]{2}{*}{16.} & Latidae & & & & & \\
\hline & 23. Later calarifer & - & - & $\mathbf{1}^{\mathrm{b}}$ & $0,17^{b}$ & $\mathbf{0 , 0 0 0}$ \\
\hline \multirow[t]{2}{*}{17.} & Dasyatidae & & & & & \\
\hline & 24. Dasyatis Americana & - & - & 1 & 0,17 & 0,341 \\
\hline
\end{tabular}

Hasil pengamatan keanekaragaman ikan yang diperoleh dari penelitian ini tergolong lebih sedikit bila dibandingkan dengan hasil penelitian (Asriyana, Sukimin, Lumban Batu, \& Kartamihardja, 2009) yakni sebanyak 45 jenis dan 30 famili dari Perairan Teluk Kendari Sulawesi Tenggara. Hasil pengamatan juga menunjukkan bahwa jenis ikan yang terbanyak ditemukan dari hutan mangrove adalah Argyrosomus Sp. (famili Scienidae) sebanyak 31,31\% dan nama lokal Belama atau Gulamah. Adapun dari pesisir pantai yang terbanyak adalah Amblygaster leiogaster (famili Clupeidae) sebanyak 44,9 \% dan memiliki nama lokal Klepes. Hasil penelitian ini berbeda dengan hasil yang diperoleh (Redjeki, 2013) yang menghitung komposisi dan kelimpahan ikan di Ekosistem Mangrove Kedungmalang, Jepara dimana ikan paling banyak ditemui adalah famili Mugilidae, sedangkan ikan yang jarang ditemui adalah Famili Belonidae.

Menurut (Praptono, 2006) penyebaran ikan Belama/ Gulamah ini tersebar di Sumatera, Jawa, hingga Kalimantan. Ikan Belamah/ Gulamah memiliki nilai ekonomis yang rendah namun memiliki kandungan protein yang cukup tinggi. Habitat ikan Belamah/ Gulamah dapat ditemukan di aliran sungai hingga muara sungai, dan perairan yang memiliki garam yang terlarut berguna sebagai macam aktivitas dalam sebuah siklus hidupnya, seperti fungsi vital yaitu makan, pencernaan, pertumbuhan, respon pada stimulus reproduksi yang bergantung pada kondisi perairan.

Uji ANOVA untuk mengetahui perbedaan jumlah jenis dan jumlah individu dari hutan mangrove dan pesisir pantai menunjukkan nilai sig lebih dari 0,05 (masingmasing 1,00 dan 0,35). Hal ini menandakan tidak ada perbedaan antara lokasi pengamatan terhadap jumlah jenis dan jumlah individu. Menurut Effendie (1997), jumlah jenis dan jumlah indvidu ikan disuatu perairan ditentukan oleh ketersediaan makanan yang akan mempengaruhi pertumbuhan, dan kematangan tiap individu serta keberhasilan hidupnya, jumlah makanan disuatu perairan dipengaruhi oleh kondisi biotik dan abiotik seperti suhu, salinitas, dan kekeruhan. Sedangkan hasil uji ANOVA (perbandingan nilai tengah antara ekosistem mangrove dengan pesisir pantai) terhadap jenis ikan menunjukkan nilai sig 0,00 untuk ikan jenis Anodontostoma chacunda, Plotosidae, dan Later calarifer.

\section{Indeks Keanekaragaman Ikan}

Indeks keanekaragaman jenis ikan dari hutan mangrove Desa Pagatan Besar diketahui lebih tinggi $(2,12)$ daripada lokasi pengamatan di pesisir pantai $(1,68)$. Menurut Magurran (1988) menyatakan bahwa keanekaragaman tinggi apabila nilai indeks keanekaragaman $\left(\mathrm{H}^{\prime}\right)>3$; sedang $1<\mathrm{H}^{\prime}<3$ dan rendah jika $\mathrm{H}^{\prime}<1$. Indeks kemerataan jenis ikan pada hutan mangrove juga menampakkan nilai yang lebih tinggi $(1,68)$, bila dibandingkan dengan pesisir pantai (1,29). Menurut Krebs (1972) bahwa keseragaman populasi tinggi apabila indeks kemerataan $(E)>0,6$; sedang $0,4<E<0,6$ dan rendah $\mathrm{E}<0,4$. Adapun untuk indeks kesamaan (similarity) jumlah jenis ikan yang ada di hutan mangrove dan pesisir pantai, maka nilainya adalah 58,3\%. Nilai yang mendekati 1 ini menunjukkan bahwa tingkat kesamaannya tinggi adapun jika mendekati 0 maka 
tingkat kesamaannya rendah. Hasil perhitungan indeks kemerataan, keanekaragaman dan kesamaan ikan antara hutan mangrove dan pesisir pantai dapat dilihat pada Tabel 2.

Tabel 2. Hasil perhitungan indeks kemerataan, keanekaragaman dan kesamaan ikan antara hutan mangrove dan pesisisr pantai di Desa Pagatan Besar Kabupaten Tanah Laut

\begin{tabular}{lcc}
\hline \multirow{2}{*}{$\begin{array}{c}\text { Indeks } \\
\text { Pengukuran }\end{array}$} & \multicolumn{2}{c}{ Nilai } \\
\cline { 2 - 3 } & Stasiun I (Hutan Mangrove) & Stasiun II (Pesisir Pantai) \\
\hline H' Index & 2,12 & 1,68 \\
\hline Evennes & 1,68 & 1,29 \\
\hline Similarity (\%) & \multicolumn{3}{c}{58,33} \\
\hline
\end{tabular}

Indeks keanekaragaman ikan dari penelitian ini berada pada kisaran 1,68 - 2,12 yang termasuk tingkat rendah. Ini setara dengan hasil penelitian dari Munafi'ah dkk. (2017), yang secara deskriptif mendapatkan hasil indeks keanekaragaman antara 1,092,0 untuk hasil tangkapan ikan dari kawasan yang terabrasi di Bedono, Kabupaten Demak. Namun jika dibandingkan dengan hasil penelitian (Wahyudewantoro, 2009) di Sungai Cigenter, Pandeglang Jawa Barat dimana indeks keanekaragaman H mencapai 2.74, dan indeks kesamarataan E mencapai 0.930, maka hasil dari penelitian ini masih berada di bawahnya.

Menurut Odum (1971), keanekaragaman dipengaruhi oleh faktor eksternal seperti tekanan eksploitasi. Hal ini juga terjadi dalam penelitian, disebabkan pesisir pantai merupakan tempat utama penangkapan ikan sehingga ini diduga menjadi penyebab indeks keanekaragamannya lebih rendah daripada hutan mangrove. Adapun menurut Scheimer \& Zalewski (1992) dalam Eko dan Jumaidi (2016), bahwa keheterogenan habitat dan kualitas air juga diperhitungkan sebagai penyebab keanekaragaman ikan di sungai. Keanekaragaman spesies yang tinggi menunjukkan keseimbangan ekosistem yang lebih baik. Sebaliknya keanekaragaman yang rendah menunjukkan sistem sedang mengalami kerusakan, misalnya bencana alam, polusi, dan lain-lain.

\section{Kelimpahan Jenis Ikan}

Rata-rata hasil tangkapan ikan dengan menggunakan jala ikan berukuran $60 \mathrm{x}$ 1,5 meter yang tertinggi diperoleh dari pesisir pantai $\left(94,17\right.$ individu/ $\mathrm{m}_{2}$ jala ikan), sedangkan dari hutan mangrove jumlahnya lebih sedikit (66 individu// $\mathrm{m}_{2}$ jala ikan). Adapun jumlah keseluruhan ikan yang berhasil ditangkap dari hutan mangrove adalah 396 individu atau lebih rendah daripada pesisir pantai (565 individu). Hasil penghitungan kelimpahan selengkapnya dapat dilihat pada Tabel 3.

Tabel 3. Perbandingan kelimpahan ikan hasil tangkapan dari ekosistem mangrove di Desa Pagatan Besar, Kabupaten Tanah Laut.

\begin{tabular}{|c|c|c|c|c|c|c|c|c|}
\hline \multirow[b]{2}{*}{ Stasiun } & \multicolumn{6}{|c|}{ Ulangan (individu) } & \multirow[b]{2}{*}{$\sum$} & \multirow[b]{2}{*}{$\mathrm{x}$} \\
\hline & 1 & 2 & 3 & 4 & 5 & 6 & & \\
\hline Hutan Mangrove & 134 & 59 & 41 & 61 & 50 & 51 & 396 & 66 \\
\hline \multirow[t]{2}{*}{ Pesisir Pantai } & 135 & 198 & 30 & 79 & 57 & 66 & 565 & 94,17 \\
\hline & \multicolumn{6}{|c|}{$\alpha=0.05$} & \multicolumn{2}{|c|}{ Sig. 1,00} \\
\hline
\end{tabular}


Jumlah ikan yang berhasil ditangkap dari penelitian ini lebih tinggi bila dibandingkan dengan hasil penelitian (Busyairi, Dewiyanti, \& Agustina, 2018) pada perairan mangrove di Gampong Jawa, Kecamatan Kuta Raja, Banda Aceh yang mendapatkan ikan dengan jumlah 167 ekor. Jumlahnya juga lebih besar dibandingkan penelitian (Gunawan \& Jumadi, 2016) yang menemukan sebanyak 198 individu saat meneliti keanekaragaman jenis dan sebaran ikan yang dilindungi, dilarang dan invasif di Kawasan Konservasi Rawadanau Banten.

Di sisi lain, hasil perbandingan nilai tengah (uji ANOVA) kelimpahan ikan yang ditemukan dari hutan mangrove dan pesisir pantai menunjukkan nilai sig. $=1,00$. Hal ini menandakan bahwa tidak ada perbedaan kelimpahan atau jumlah ikan yang ditemukan dari hutan mangrove dengan pesisir pantai.

\section{E. Kondisi Substrat pada Hutan Mangrove dan Pesisir Pantai}

Hasil analisis substrat tanah dari hutan mangrove (Tabel 4) diketahui bahwa komposisi tertinggi adalah debu $(82,35 \%)$, liat $(16,33 \%)$ dan terendah pasir $(1,31 \%)$. Kondisi substrast pada pesisir pantai menunjukkan bahwa yang tertinggi adalah pasir $(96,21 \%)$, liat $(3,30 \%)$ dan terendah debu $(0,49 \%)$.

Tabel 4. Hasil pengukuran kandungan substrat pada hutan mangrove dan pesisir pantai

\begin{tabular}{ccccc}
\hline No. & Stasiun & \multicolumn{3}{c}{ Komponen $(\%)$} \\
\cline { 3 - 4 } & & Pasir & Debu & Liat \\
\hline 1. & Hutan Mangrove & $\mathbf{1 , 3 1}^{\mathbf{a}}$ & $\mathbf{8 2 , 3 5}^{\mathbf{b}}$ & $\mathbf{1 6 , 3 3}^{\mathbf{b}}$ \\
\hline 2. & Pesisir Pantai & $\mathbf{\mathbf { 6 , 2 1 } ^ { \mathbf { b } }}$ & $\mathbf{0 , 4 9}^{\mathbf{a}}$ & $\mathbf{3 , 3 0}^{\mathbf{a}}$ \\
\hline & Sig. & 0,000 & 0,000 & 0,000
\end{tabular}

Keterangan: $\alpha=0.05$, a dan b (berbeda signifikan antara stasiun I dan stasiun II)

Kadar substrat yang diperoleh dalam penelitian ini terutama kandungan debu pada hutan mangrove dari penelitian ini adalah lebih tinggi $(82,35 \%)$ dibandingkan hasil penelitian (Susiana, 2011), sebesar 72,63 \% yang didominasi oleh Rhizophora stylosa dan Rhizophora mucronata. Hasil uji perbedaan nilai tengah menggunakan ANOVA antara pasir, debu, dan liat menunjukkan nilai $0,00(<0,05)$, sehingga dapat diartikan bahwa terdapat perbedaan antara komponen (pasir, debu, dan liat) yang dijumpai pada hutan mangrove dan pesisir pantai. Ukuran partikel substrat merupakan salah satu faktor ekologis utama dalam mempengaruhi struktur komunitas seperti kandungan bahan organik yang terdapat pada substrat (Nybakken, 1992).

\section{E. Kondisi Air pada Hutan Mangrove dan Pesisir Pantai}

Secara umum, hasil pengujian kualitas air pada ekosistem mangrove lebih rendah daripada pesisir pantai. Tercatat pada hutan mangrove nilai rata-rata $\mathrm{pH}=6,68$, $\underline{\text { Suhu }}=26^{\circ} \mathrm{C}$, Salinitas $=9,72 \%$ dan kekeruhan 5,20 NTU. Sedangkan pada pesisir pantai Desa Pagatan Besar nilai rata-rata $\mathrm{pH}=7,38$, Suhu $=32{ }^{\circ} \mathrm{C}$, Salinitas $=53,5 \%$ dan kekeruhan 353 NTU. Hasil pengukuran kandungan air pada hutan mangrove dan pesisir pantai dapat dilihat pada Tabel 5 di bawah ini : 
Tabel 5. Hasil pengukuran kandungan air pada perairan hutan mangrove dan pesisir pantai di Desa Pagatan Besar, Kabupaten Tanah Laut

\begin{tabular}{|c|c|c|c|c|c|}
\hline \multirow[b]{2}{*}{ No. } & \multirow[b]{2}{*}{ Parameter Uji } & \multicolumn{2}{|c|}{ Hasil Uji } & \multirow[b]{2}{*}{ Metode Uji } & \multirow[b]{2}{*}{ Sig. } \\
\hline & & $\begin{array}{c}\text { Hutan } \\
\text { Mangrove }\end{array}$ & $\begin{array}{l}\text { Pesisir } \\
\text { Pantai }\end{array}$ & & \\
\hline 1. & $\mathrm{pH}$ & $6,68^{\mathrm{a}}$ & $7,38^{\mathrm{b}}$ & $\begin{array}{c}\text { SNI 06-6989 11- } \\
2004\end{array}$ & 0,000 \\
\hline 2. & Suhu & $26^{\circ} \mathrm{C}^{\mathrm{a}}$ & $32^{\circ} \mathrm{C}^{\mathrm{b}}$ & Celcius & 0,000 \\
\hline 3. & Salinitas & $9,72 \%$ & $53,5 \%$ & Konduktrimetri & Tidak diuji \\
\hline 4. & Kekeruhan & $5,20 \mathrm{NTU}$ & $353 \mathrm{NTU}$ & Nephelometrik & Tidak diuji \\
\hline
\end{tabular}

Kondisi perairan (Nilai pH dan suhu) dari penelitian ini setara dengan hasil (Rahman, 2016) mengenai produktivitas primer perairan pantai kawasan hutan mangrove di Desa Pagatan Besar Kecamatan Takisung Kabupaten Tanah Laut dimana $\mathrm{pH}$ berada pada kisaran 6,67 - 7 dan suhu pada kisaran nilai $27,5-29^{\circ} \mathrm{C}$. Kemudian nilainya juga mirip dengan hasil penelitian (Hamuna, Tanjung, Suwito, Maury, \& Alianto, 2018) mengenai kualitas air laut dan indeks pencemaran berdasarkan parameter fisika-kimia di Perairan Distrik Depapre, Jayapura yang memperoleh nilai $\mathrm{pH}$ sekitar $6,58-7,13$ dan suhu antara $29,2-29,6^{\circ} \mathrm{C}$.

Hasil uji perbedaan nilai tengah menggunakan ANOVA pada faktor lingkungan pH dan suhu memiliki nilai sig. 0,00 atau lebih kecil dari 0,05. Ini menandakan bahwa terdapat perbedaan kedua faktor tersebut pada lokasi pengamatan di hutan mangrove dengan pesisir pantai. Menurut (Brower, 1997) suhu perairan merupakan parameter fisika yang sangat mempengaruhi pola kehidupan biota akuatik seperti penyebaran, kelimpahan, dan mortalitas. Adapun (Pescod, 1973) mengatakan bahwa organisme mempunyai kemampuan berbeda dalam mentoleransi $\mathrm{pH}$ perairan. Dan kematian organisme lebih sering terjadi karena $\mathrm{pH}$ yang rendah daripada $\mathrm{pH}$ yang tinggi.

\section{KESIMPULAN}

1. Jumlah jenis ikan yang ditemukan pada ekosistem mangrove di Desa Pagatan Besar Kabupaten Tanah Laut lebih sedikit (12 jenis) dari pada pesisir pantai (15 jenis). Rata-rata kelimpahan jumlah ikan dari hutan mangrove juga lebih kecil (66 individu $/ \mathrm{m}_{2}$ jala ikan) dari pesisir pantai ( 94,17 individu/ $\mathrm{m}_{2}$ jala ikan),

2. Jenis ikan yang terbanyak ditemukan dari hutan mangrove adalah Argryosomus Sp.(nama lokal ikan Belama) dengan tingkat kehadiran 31,31\%. Sedangkan dari pesisir pantai adalah jenis Amlygaster leiogaster (nama lokal Klepes) dengan tingkat kehadiran sebanyak 44,9\%.

3. Indeks keanekaragaman jenis ikan dari hutan mangrove Desa Pagatan Besar tergolong relatif sedang $\left(\mathrm{H}^{\prime}<3\right)$ yakni pada nilai 2,12 dan lebih kecil di pesisir pantai sebesar 1,68. Indeks kemerataan ikan dari hutan mangrove dan pesisir pantai menunjukkan nilai populasi tinggi $(E>0,6)$ sebesar 0,72. Sedangkan indeks kesamaannya berada pada kisaran nilai sebesar 0,58 .

4. Substrat tanah dari hutan mangrove lebih banyak mengandung lumpur/debu $(82,35 \%)$, sedangkan substrast dari pesisir pantai lebih banyak mengandung pasir $(96,21 \%)$. Kualitas air dari hutan mangrove lebih rendah daripada pesisir pantai. 


\section{DAFTAR PUSTAKA}

Allen, G. . (2000). Marine Fishes of South-East Asia: A Field Guide for Anglers and Divers. Hong Kong, China: Periplus Editions (HK) Ltd.

Asriyana, R. M. F., Sukimin, S., Lumban Batu, D. T. F., \& Kartamihardja, E. S. (2009). Keanekaragaman Ikan di Perairan Teluk Kendari, Sulawesi Tenggara. Jurnal Iktiologi Indonesia, 9(2), 98. Retrieved from blob:http://jurnal-iktiologi.org/e0cbabfd-c151-453e-b28c-4f645b8be0e3

Boyd, C. (2003). The status of codes of practice in aquaculture. In World Aquaculture (Vol. 34, pp. 6366).

Brower, J. (1997). Field and Lab Methods For General Ecology. McGraw-Hill Education (ISBN/ASIN:). McGraw-Hill Education.

Busyairi, A., Dewiyanti, I., \& Agustina, S. (2018). Keanekaragaman jenis ikan di Perairan Mangrove Gampong Jawa, Kecamatan Kuta Raja, Banda Aceh. Jurnal Ilmiah Mahasiswa Kelautan Dan Perikanan Unsyiah, 3(Februari), 7-13. $\quad$ Retrieved from http://jim.unsyiah.ac.id/fkp/article/download/8510/3560

Gunawan, E. H., \& Jumadi. (2016). Keanekaragaman Jenis dan Sebaran Ikan yang Dilindungi, Dilarang Dan Invasif Di Kawasan Konservasi Rawadanau Banten. Jurnal Perikanan Dan Kelautan, 6 No.1(Juni), 67-73. Retrieved from https://www.researchgate.net/profile/Eko_Gunawan2/publication/338006973_Jurnal_Eko_Hendri/li nks/5df9f5b3299bf10bc3636c5c/Jurnal-Eko-Hendri.pdf?origin=publication_detail

Hamuna, B., Tanjung, R. H. R., Suwito, S., Maury, H. K., \& Alianto, A. (2018). Kajian Kualitas Air Laut dan Indeks Pencemaran Berdasarkan Parameter Fisika-Kimia di Perairan Distrik Depapre, Jayapura. Jurnal Ilmu Lingkungan, 16(1), 35. https://doi.org/10.14710/jil.16.1.35-43

Hendrata, S. (2004). Pemanfaatan ikan nila (Oreochromis niloticus) sebagai bioindikator untuk menilai efektifitas kinerja IPAL Rumah Sakit Pupuk Kaltim, Bontang. Retrieved from http://eprints.undip.ac.id/11504/1/2004MIL3227.pdf

Kottelat, M., Whitten, A. J., Kartikasari, S. N., \& Wirjoatmodjo, S. (1993). Ikan Air Tawar Indonesia Bagian Barat dan Sulawesi. Jakarta: Periplus Edition (HK) Ltd. Bekerjasama dengan Proyek EMDI, Kantor Menteri Negara Kependudukan dan Lingkungan Hidup Republik Indonesia.

Krebs, C. . (1972). Ecology, The Experimental Analysis of Distribusi and Abundance. London: Harper and Rows Publisher.

Nasution, S. H., Sulistiono, S. D. S., \& Haryani, G. S. (2004). Variasi Morfologi Ikan Endemik Rainbow Selebensis (Telmatherina celebensis Boulenger) Di Danau Towuti, Sulawesi Selatan. Jurnal Akuakultur Indonesia, 3(2), 5-11. Retrieved from https://www.researchgate.net/profile/Sulistiono_Sulistiono3/publication/320272987_VARIASI_M ORFOLOGI_IKAN_ENDEMIK_RAINBOW_SELEBENSIS_Telmatherina_celebensis_BOULEN GER_DI_DANAU_TOWUTI_SULAWESI_SELATAN_Morfological_Variation_of_Endemic_Fis h_Rainbow_Celebensi

Nybakken, J. . (1992). Biologi laut: suatu pendekatan ekologis. Jakarta: PT Gramedia Pustaka Utama.

Pescod, M. (1973). Investigation of Rational Effluent and Stream Standards for Tropical Countries. Bangkok: AIT.

Praptono, B. (2006). Produksi Pepton Ikan Gulamah (Argyrosomus sp.) sebagai Sumber Nitrogen Media Pertumbuhan Mikroba. Bogor.

Puteri, D., Sitorus, H., \& Muhtadi, A. (2017). Keragaman ikan di perairan ekosistem mangrove Desa Jaring Halus Kabupaten Langkat, Sumatera Utara. Depik - Jurnal Ilmu-Ilmu Perairan, Pesisir Dan Perikanan, 6(2), 145-152. https://doi.org/10.13170/depik.6.2.6656

Rahman, M. (2016). Produktivitas primer perairan pantai kawasan hutan mangrove Desa Pagatan Besar Kecamatan Takisung Kabupaten Tanah Laut Propinsi Kalimantan Selatan. Fish Scientiae, 6(Nomor 11, Juni), 11-24. 
88 Jurnal Teknosains, Volume 14, Nomor 1, Januari-Juni 2020, hlm. 80 - 88

Redjeki, S. (2013). Komposisi dan Kelimpahan Ikan di Ekosistem Mangrove di Kedungmalang, Jepara. Jurnal Ilmu Kelautan, 18 (1)(Maret 2013), 56-62. https://doi.org/10.1136/bmj.c5945

Saanin, H. (1984). Taksonomi dan Kunci Identifikasi Ikan Jilid 1 dan 2. Jakarta: Bina Cipta.

Susiana. (2011). Diversitas dan Kerapatan Mangrove, Gastropoda, dan Bivalvia di Estuari Perancak, Bali. Makassar.

Wahyudewantoro, G. (2009). Keanekaragaman fauna ikan ekosistem mangrove di Kawasan Taman Nasional Ujung Kulon, Pandeglang-Jawa Barat. Berita Biologi, 9(April), 379-386. 